\title{
Meta
}

Journal des traducteurs

Translators' Journal

\section{DURAND, Michel et Martin HARVEY (1992) : Méthode et pratique du thème anglais, Paris, Dunod, 261 p.}

\section{Paul St-Pierre}

Volume 39, numéro 3, septembre 1994

URI : https://id.erudit.org/iderudit/004301ar

DOI : https://doi.org/10.7202/004301ar

Aller au sommaire du numéro

Éditeur(s)

Les Presses de l'Université de Montréal

ISSN

0026-0452 (imprimé)

1492-1421 (numérique)

Découvrir la revue

Citer ce compte rendu

St-Pierre, P. (1994). Compte rendu de [DURAND, Michel et Martin HARVEY

(1992) : Méthode et pratique du thème anglais, Paris, Dunod, 261 p.] Meta, 39(3),

483-484. https://doi.org/10.7202/004301ar

Ce document est protégé par la loi sur le droit d'auteur. L'utilisation des services d'Érudit (y compris la reproduction) est assujettie à sa politique d'utilisation que vous pouvez consulter en ligne.

https://apropos.erudit.org/fr/usagers/politique-dutilisation/
Cet article est diffusé et préservé par Érudit.

Érudit est un consortium interuniversitaire sans but lucratif composé de l’Université de Montréal, l’Université Laval et l’Université du Québec à Montréal. Il a pour mission la promotion et la valorisation de la recherche. https://www.erudit.org/fr/ 
DURAND, Michel et Malcolm HARVEY (1992): Méthode et pratique du thème anglais, Paris, Dunod, 261 p.

This manual of translation from French into English is aimed essentially at university students and teachers in France, although the target audience also includes professional translators. The former are indeed likely to find the manual useful, in particular for the thorough explanations of English grammar and usage and the pertinent examples, taken in many cases from the texts translated in the second part of the book. Professional translators, on the other hand, are much less likely to find the manual suitable for their needs, other than for occasional consultation, and the lack of an index makes such consultation exceedingly difficult.

The title of the book is somewhat misleading in its claim to provide a method of translation. Except for six pages or so at the beginning of the book and a chapter on the translation of proper names, there is no general consideration of problems related to translation methodology as such. Instead, more than 150 pages are devoted to purely linguistic problems posed by translation from French into English. This weakness of the work is in a sense also one of its strengths, since the explanations are for the most part clear, useful and complete, although the treatment of the "s-genitive and the verbal system in English in particular could be more comprehensive. In its first section then, the manual differs in fact little from traditional grammars of English since the process of translation as such is only occasionally referred to. The second section - the forty texts and their translations, divided into three levels of difficulty - is also somewhat problematic. Here the work situates itself exclusively within the European context: each level contains a 
section related to life in Great Britain; linguistic and stylistic choices (punctuation, for example) are resolutely British. This renders the work of little use to North Americans, which is unfortunate since it would have been a relatively simple matter to adjust the choice of texts and their translations to reflect both usages and contexts. To have done so would have been of use to the defined target audience as well, since translators working in France need to be familiar with more than just British usage. This decision by the authors leads to oddities such as using a colloquial British term in a quotation from an American actress (Text 10: "provided they're moneyspinners"). Another difficulty in this second part is the translation of the names of specifically French institutions. "Si les associations d'étudiants en LEA" becomes "Although students" associations in Applied Modern Languages ('LEA')" (Text 14) and "CNRS" is rendered "CNRS (French National Scientific Research Centre)" (Text 3). The reader of the translations is left somewhat bewildered as to the connection between the capital letters and the English name given in parentheses. A much better solution would have been to have used the French acronym and a footnote providing the French name in full and its English equivalent. Finally, the one-page selective bibliography provided is entirely inadequate; in a book claiming to provide a methodology one could have expected that a wide selection of the bibliographical tools available to translators would have been listed.

It should nevertheless be stressed that the grammatical explanations the authors provide are clear and sufficiently complex that most difficult cases confronting translators, and teachers and students of translation, could be satisfactorily resolved using this text. Because of this, it can only be hoped that improvements will be made to the manual in a second edition.

PAUL ST-PIERRE 